\title{
Sri Lanka in 2012
}

Securing the State, Enforcing the "Peace"

\begin{abstract}
Since the end of the civil war in May 2009, Sri Lanka's government has continued to consolidate the unitary state and centralize power by combining political reform, patronage, and economic development. However, two forces countering such unity and centralization became evident during the course of the year. First, tensions and contradictions associated with the simultaneous pursuit of political centralization alongside rapid economic development and liberalization. Second, there has been an intensification of external pressures to bring about a political settlement with the Tamils and to address government accountability, including its alleged involvement in war crimes.
\end{abstract}

KEYWORDS: constitutional reform, political centralization, economic liberalization, accountability and war crimes, international pressure

\section{PROVINCIAL COUNCIL ELECTIONS AND POLITICAL OPPOSITION}

IN 2OI2, the Rajapaksa government continued to consolidate its position by holding early Provincial Council elections, repressing political opposition in the south and northeast, and introducing far reaching reforms that, if implemented, would further concentrate power in the executive. These developments have met with some domestic friction and resistance, particularly from the judiciary and Tamil political parties, but, in the main, little has countered these centralizing tendencies.

Early Provincial Council elections were called as a tactical buildup to early parliamentary and presidential elections, as the government wanted to go to the polls while its popularity remained high. Elections for three of the eight

Jonathan Goodhand is Professor of Conflict and Development Studies in the Development Studies Department of the School of Oriental and African Studies, University of London. He has 20 years of experience working in or on Sri Lanka and has published widely on conflict and development issues, including the peace process, humanitarian aid, and post-conflict reconstruction.

Asian Survey, Vol. 53, Number I, pp. 64-72. ISSN ooo4-4687, electronic ISSN 1533-838X. (C) 2013 by the Regents of the University of California. All rights reserved. Please direct all requests for permission to photocopy or reproduce article content through the University of California Press's Rights and Permissions website, http://www.ucpressjournals.com/reprintInfo.asp. DOI: AS.20I3.53.I.64. 
Provincial Councils (North Central, South West, and Eastern) took place on September 8. According to independent observers, they were neither free nor fair. Yet, the results in the south, where the United Peoples Freedom Alliance (UPFA) ruling coalition won $60 \%$ of the vote, clearly reflected continued support for the government in the majority Sinhalese electorate. In the ethnically mixed Eastern Province (40\% Muslim, 35\% Tamil, and $25 \%$ Sinhalese), the results were less clear cut. The government failed to win a majority of seats there, though ultimately it managed to patch together a majority coalition. The Tamil National Alliance (TNA), which had boycotted the 2008 provincial election, got the vast majority of Tamil votes, consolidating its position as the voice of the Tamil people. Given that the TNA would likely repeat this result in the Northern Provincial Council elections due in 20I3, this will increase the UPFA's reluctance to hold the elections in the north. The Provincial Council system was introduced under the 13th Amendment to the Constitution in 1987 in order to address Tamil grievances by devolving power to the north and east. Paradoxically, Provincial Councils are now functioning in all provinces except the one with a Tamil majority.

The elections also highlight the continued decline of the main opposition party, the right-leaning United National Party (UNP). It has been undermined by leadership conflicts, party crossovers, and a lack of grassroots mobilization in recent years. While the TNA may be a thorn in the side of the UPFA in the north, where Tamils are the majority population, in the Sinhalese-majority south there is no credible opposition to the current regime.

The government continues to deal harshly with other potential sources of opposition, including critical voices in civil society, the media, and the judiciary. Since the end of the civil war, roughly one person has been abducted or "disappeared" every five days. ${ }^{1}$

\section{THE DIVINEGUMA BILL AND HIGH COURT IMPEACHMENT}

In addition to confirming its mandate at the ballot box and repressing domestic opposition, the government has sought to introduce reforms that undermine both the checks and balances on the executive as well as the

I. "A Disappearance Every Five Days in Post War Sri Lanka," Groundviews, August 30, 2012, $<$ http://groundviews.org/2012/o8/3o/a-disappearance-every-five-days-in-post-war-sri-lanka/>, accessed December I, 2012. 
long term prospects of a political settlement to the Tamil question. The Divineguma Bill (Uplifting Lives) presented to Parliament in August, aimed to establish a superministry in the form of a Divineguma Department and to consolidate economic resources that were previously controlled by statutory government authorities and elected Provincial Councils.

The proposed law was challenged in the Supreme Court on behalf of the sole non-functioning Provincial Council—the Northern Province. Supreme Court Chief Justice Shirani Bandaranayake ruled that the Divineguma Bill must be approved by all the Provincial Councils before it can be passed by Parliament. This led to retaliatory action by the government in the form of impeachment proceedings against Bandaranayake; a parliamentary select committee found her guilty of professional misconduct in December, but in January 2013 an appeals court found the moves to impeach the chief justice unlawful. ${ }^{2}$ In its efforts to centralize power, the government appears to be determined to eliminate the possibility of future obstruction by the courts or Provincial Councils. The impeachment threatens to further undermine judicial independence and has led to protests from diverse sources, including the four chief priests of the Buddhist Sangha (Assembly) and the Bar Association. The bill can be seen as consistent with, and complementary to, the I8th Amendment passed in 20II. ${ }^{3}$ Together, these constitute an attempt to concentrate unprecedented political and financial powers in the presidency.

\section{POLITICAL SETTLEMENT AND THE NORTH EAST}

Since the end of 20II, political negotiations between the TNA and the government have remained suspended. Negotiations were to occur through a Parliamentary Select Committee (PSC), but this has not yet been constituted because the TNA refused to give nominations unless certain preconditions were met by the government. ${ }^{4}$ The UPFA government calculates that

2. In spite of this ruling, the president subsequently dismissed Bandaranayake, and a new chief was appointed in January.

3. The I8th Amendment's main changes were the removal of presidential term limits, previously set at a maximum of two six-year terms; the I7th Amendment was repealed, which provided checks on the powers of the president; and the election commission lost its power to prevent the use of state resources during elections.

4. The PSC will have 3I members of which five will be from the TNA. Given its weak representation, the TNA has made its participation in the PSC conditional on a guarantee from the government that the agenda for discussions would not go below a certain existing devolution threshold. 
with its two-thirds parliamentary majority and its electoral vote base in the south, it can either safely ignore minority demands or coopt their representatives into the government coalition by giving them Cabinet posts in return for political support.

The TNA's room for maneuver is extremely limited, as it is squeezed by government demands and threats, on the one hand, and Tamil diaspora and diplomatic pressures, on the other. Although the TNA has shown a willingness to compromise on some issues in order to start talks, ${ }^{5}$ it has adopted a hardline position on others, including its unambiguous rejection of the Lessons Learned and Reconciliation Committee (LLRC, see below) and its choice to focus on the question of accountability rather than the material interests and concerns of Tamils living in the north and east. This arguably plays into Rajapaksa's attempt to portray the TNA as a rump of the Liberation Tigers of Tamil Eelam (LTTE), beholden to the diaspora rather than concerned with the socioeconomic and political aspirations of Tamils within the country. ${ }^{6}$

Apart from external pressures, there are challenges from within Sri Lanka to the TNA from Tamil nationalist civil society and those associated with the Tamil National People's Front (TNPF) ${ }^{7}$ led by Gajen Ponambalam, a former TNA parliamentarian. They argue that the TNA is being pulled into "normal," Sri Lankan patronage-based politics by a combination of government threats and incentives, along with international diplomatic pressure from the U.S. and India. There is also increasingly vocal activism in the Tamilmajority Indian state of Tamil Nadu, as parties there have ratcheted up concerns over Sri Lankan Tamils, often for political gains. For example, recently re-elected Tamil Nadu Chief Minister Jayalalitha has urged Delhi to put pressure on Colombo and has interceded to block the training of Sri Lankan military personnel in Tamil Nadu.

External efforts to break the TNA-Sri Lankan government deadlock have had little impact despite U.S. and Indian shuttle diplomacy. Following the Norwegian peace facilitation experience from 2002-08, in which the Sinhalese

5. For example, the leader of the TNA met with three members of the government delegation on January 27,2012 , and made several concessions. It was agreed that the TNA would nominate names to the PSC simultaneously with the recommencement of the bilateral talks and that the PSC would be convened only after substantial agreement was reached at the bilateral talks.

6. International Crisis Group, "Sri Lanka: Tamil Politics and the Quest for a Political Solution," Asia Report, no. 239 (November 2012).

7. Launched on February 28, 20I0, the TNPF is a breakaway faction of the TNA. Its main constituent is the All Ceylon Tamil Congress. 
south feared that negotiations might lead to the division of the country, there has been a heightened sensitivity to any form of external mediation. The government's military victory over the LTTE in 2009 further eroded the legitimacy, and the perceived necessity, of mediation. The government has refused to clarify its position on what powers should be devolved to the provinces in spite of assurances to India, U.N., and U.S. officials that it would fully implement, or go beyond, the I3th Amendment. ${ }^{8}$

In the north and east, the government's focus is on economic development rather than political devolution. The postwar economic rebound has continued, supported by major infrastructure projects (including roads, railways, ports, airports, the northern power grid, and a Jaffna-Kilinochchi water and sanitation system); increased trade between the Tamil north and Sinhalese south; and the growth of agriculture and fishing.

However, the TNA has been unable to win any significant concessions for political normalization in the north. Although troop levels have been reduced in the Jaffna Peninsula, this has not been the case on the Vanni mainland. The civil administration runs in parallel to, and is frequently overruled by, a separate military architecture. ${ }^{9}$ There is, as yet, limited evidence of systematic and large-scale Sinhala colonization of Tamil regions. Creeping Sinhalization, on the other hand, is occurring in the form of appointments of Sinhala government officials, the renaming of roads and villages, the growth of military monuments and museums, and the erection of Sinhala signboards and Buddha statues. Militarization (also an agent of Sinhalization because the army is almost entirely from the majority community) continues with the construction of large and permanent military cantonments in the north, making up a comprehensive security complex of major base camps linked to a system of detachments and satellite camps. ${ }^{10}$ Military surveillance of the population occurs through a network of Tamil informers, some of whom have been recruited from the pool of recently released LTTE detainees. However, the government's hegemony in the north does not go uncontested.

8. It has been assumed negotiations would revolve around the precise details of the degree of devolution to the provinces-whether in the form of a I3th Amendment "plus" involving more substantive regional autonomy than that contained in the original legislation, or in the form of a I $3^{\text {th }}$ Amendment "minus," which would involve a more limited arrangement in which some powers were devolved but the center retained responsibility for land and policing.

9. International Crisis Group, "Sri Lanka's North II: Rebuilding under the Military," Asia Report, no. 220 (March 16, 2012), p. I5.

Io. Ibid. 
There have been protests over land issues, for example. And on November 28 (named "Heroes' Day" by the LTTE), there was a clash between Jaffna University Tamil students holding a ceremony to remember the war dead and the police who tried to break up the gathering and arrested six students.

Over time, though, the political voice of the Tamils is likely to be undermined by demographic trends. Sri Lanka's first national census in 30 years has shown a $20 \%$ drop in the population of the Jaffna Peninsula, the long-time base of Tamil rebels during the island's ethnic conflict from 1983-2009. One likely consequence of the new census figures will be a reduction in Tamil representation in the national Parliament. Nine seats are currently allocated for Jaffna, but this could drop to six.

\section{ECONOMIC LIBERALIZATION AND CRONY CAPITALISM}

The post war economic rebound continued in 2012 based upon the four pillars of reconstruction in the north and east, infrastructure spending, business investment, and rising property investment. Tourist arrivals during the first eight months of the year grew by $16 \%$ from the previous year, and the government has targeted one million arrivals for 20I2. In April, the International Monetary Fund (IMF) completed its seventh review of Sri Lanka's performance under a program supported by a stand-by agreement and approved the release of a further $\$ 426$ million, out of a larger $\$ 2.6$ billion loan approved in 2009. In August, China pledged a further \$I.I billion in concessional loans toward the construction of the second phase of the Southern Province's Hambantota port and railway facilities.

However, a poor monsoon season and weakening external demand have dampened growth. Real GDP growth is predicted to slow to $6.7 \%$ in 2012 from an estimated $8 \%$ in $201{ }^{11}$ There are also questions about the sustainability and political impacts of the postwar rebound. A visiting IMF delegation raised concerns about balance of payments problems given an increasing trade deficit, falling foreign reserves, and an unsustainable rupee peg. These concerns have been accentuated by increased global oil prices and U.S. sanctions on Iran, the source for $90 \%$ of Sri Lanka's oil. The annual average consumer inflation rate was an estimated $7.2 \%$ in 2012. Moreover, in an attempt to create an "investment friendly" environment, the Colombo 
government has embarked upon what has been characterized as a "second wave of neoliberalism" after the "first wave" of $1977 .{ }^{12}$

The collapse of the Colombo Stock Exchange, from one of the best performing markets in the world two years ago to one of the worst performing this year, is indicative of the volatility associated with the government's financialization strategy. It may also be an early sign that, with the growth of crony capitalism, the financial interests of the regime are now beginning to trump the larger interests of national and global capital. ${ }^{13}$ The credibility of the government with international investors is low; scandals in the stock market and in major economic projects, such as those involving power generation, are not being investigated.

In the 2013 budget, the biggest allocation went to the Ministry of Defence and Urban Development, amounting to Sri Lankan Rs 290 billion (\$2.25 billion), an increase of Rs 60 billion ( $\$ 460$ million) from 20I2. While defense spending has remained at around $3 \%$ of GDP for the past few years, it makes up $20 \%$ of total expenditures - dwarfing those on education and health.

Containing current spending will be difficult because of the political imperative to increase expenditure on the civil service and military. With mounting economic pressure, particularly related to IMF austerity measures, the regime is in danger of losing its social base. This base showed signs of instability and resistance during the year, such as in strikes involving lawyers, doctors, university teachers, and railway workers. Each had their own particular causes and dynamics, but all are perhaps manifestations of growing dissatisfaction in the south with the Rajapaksa regime. At the present moment, however, there is no political party or leadership with the potential to unite these diverse sources of discontent. At the same time, nationalist insecurities stoked by the war crimes issue (see below) and the Tamil diaspora, play a role in keeping the regime's support base in line and preventing southern discontent from boiling over.

\section{HUMAN RIGHTS AND ACCOUNTABILITY}

The government may have calculated that the pressure to address the issue of war crimes and accountability for civilian casualties at the end of the conflict p. 28.

I2. Ahilan Kadirgamar, "Stockmarket Crisis and Oligarchic Interests," Island, August 25, 2012, I3. Ibid. 
would recede through a combination of the passage of time and the activities of its own LLRC, formed in May 20Io. However, external pressure from the international community has continued to grow. Although the LLRC was criticized for evading the core question of accountability, its recommendations presented in December 20II did provide a basis for moving forward on a number of key issues including devolving power, demilitarizing the Tamil northeast, and dealing with the political roots of the conflict through devolution. However, the LLRC report generated no political and institutional momentum to implement the recommendations, leading to continued frustration among international actors.

In March 20I2, a U.S.-sponsored resolution on "Promoting Reconciliation and Accountability in Sri Lanka" was passed at the I9th session of the U.N. Human Rights Council (UNHRC), calling for the implementation of the LLRC recommendations. India played a pivotal role by backing the resolution while helping to dilute the final text, confounding Sri Lanka's expectation of support from its neighbor. The Indian role can be interpreted as a clear sign of Delhi's frustration with the Sri Lankan government's failure to make any progress toward a political settlement. It can also be interpreted as a signal to disabuse the Rajapaksas of the value of their "China card" and the potential for them to exploit strategic competition between India and China. In spite of China's growing presence in the country, India remains the regional hegemon with greater geostrategic interests and economic investments in Sri Lanka. Delhi's position has consistently been to advocate for implementation of the 13 th Amendment, and growing pressure from Tamil Nadu has lent new urgency to showing progress on this issue.

In response to the UNHRC resolution, the government produced a National Action Plan to implement the recommendations of the LLRC. But critics of the action plan argue that it largely sidesteps the central issue of independent investigations into alleged war crimes and the need to restore the independence of the police, judiciary, and other public bodies from the executive. On November I, the U.N. Periodic Review took place, again placing the human rights record of the Sri Lankan government under the spotlight. International attention is likely to be maintained in 2013, with the holding of the 22nd session of the UNHRC in March and the Commonwealth Heads of Government Meeting (CHOGOM) in Colombo in November (which the Canadian government is threatening to boycott). 


\section{CONCLUSIONS}

The year has seen the Rajapaksa administration further consolidate its power base by pursuing a strategy of rapid economic growth and centralizing reforms. Provincial Council elections in the south confirm that the strategy is working for now, and the government retains the support of its core Sinhalese constituency. The resolution of the Tamil question appears to be more distant than ever, and the main drivers of change are not likely to come from the Tamil polity. Instead, such change will likely be the result of increasing international pressure on accountability and growing discontent in the Sinhalese south about repression, corruption, and the uneven effects of liberalization across the country. 